This item was submitted to Loughborough's Research Repository by the author.

Items in Figshare are protected by copyright, with all rights reserved, unless otherwise indicated.

\title{
Hybrid ventilation for low energy building design in south China
}

PLEASE CITE THE PUBLISHED VERSION

PUBLISHER

(C) Elsevier

VERSION

AM (Accepted Manuscript)

LICENCE

CC BY-NC-ND 4.0

REPOSITORY RECORD

Ji, Yingchun, Kevin J. Lomas, and Malcolm J. Cook. 2019. "Hybrid Ventilation for Low Energy Building Design in South China”. figshare. https://hdl.handle.net/2134/5273. 
This item was submitted to Loughborough's Institutional Repository (https://dspace.lboro.ac.uk/) by the author and is made available under the following Creative Commons Licence conditions.

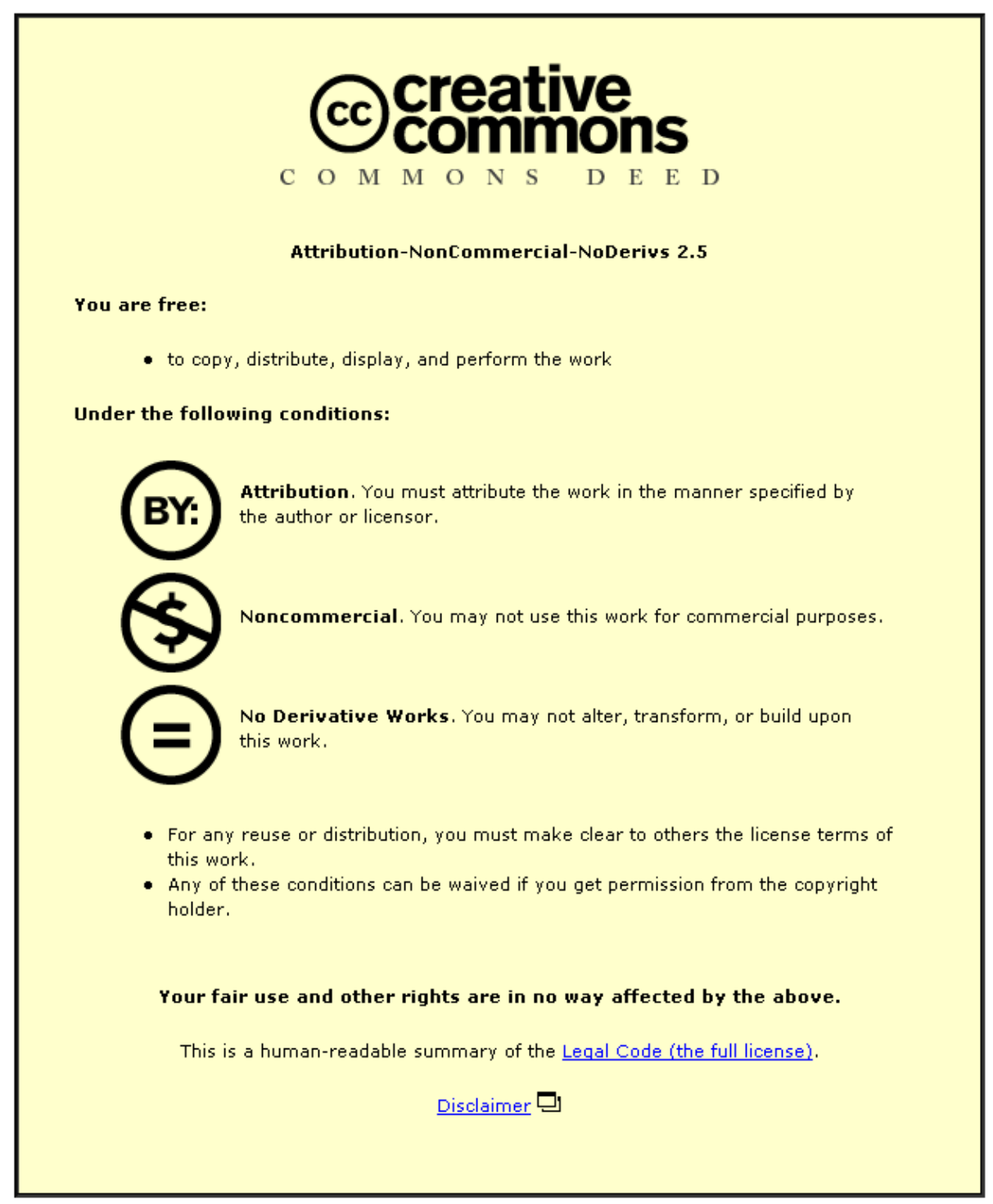

For the full text of this licence, please go to: http://creativecommons.org/licenses/by-nc-nd/2.5/ 


\title{
Hybrid ventilation for low energy building design in south China
}

\author{
Yingchun $\mathrm{Ji}^{\mathrm{a}, *}$, Kevin J. Lomas ${ }^{\mathrm{b}}$, Malcolm J. Cook ${ }^{\mathrm{b}}$ \\ ${ }^{a}$ Institute of Energy and Sustainable Development, De Montfort University, Queens Building, The Gateway, Leicester LE1 9BH, UK \\ ${ }^{\mathrm{b}}$ Department of Civil and Building Engineering, Loughborough University, Leicestershire LE11 3TU, UK \\ * Corresponding author
}

\begin{abstract}
Buildings and their related activities are responsible for a large portion of the energy consumed in China. It is therefore worthwhile to investigate methods for improving the energy efficiency of buildings. This paper describes a low energy building design in Hangzhou, south China. A hybrid ventilation system which employs both natural and mechanical ventilation was used for the building due to the severity of the climate. The passive ventilation system was tested using computational fluid dynamics (CFD) and the results showed that, in the mid-seasons, natural ventilation for the building is viable. The likely thermal performance of the building design throughout the year was evaluated using dynamic thermal simulation (DTS) with local hourly standard weather data. It is evident from the modelling results that the hybrid ventilation system is a feasible, low energy approach for building design, even in sub-tropical climates such as south China.
\end{abstract}

\section{Introduction}

Climate change is one of the major concerns the world currently faces. Increasing evidence has shown that the accumulation of greenhouse gases such as $\mathrm{CO}_{2}$ in the atmosphere is the main reason behind global warming. The increase in the average global temperature in the 20th century has been $0.74 \pm 0.18 \mathrm{~K}$ $\left(1.33 \pm 0.32{ }^{\circ} \mathrm{F}\right)$ and the projected average temperature increase for the next 100 years is severe, $1.1-6.4 \mathrm{~K}$ (or $2.0-11.5^{\circ} \mathrm{F}$ ). The temperature rise is likely to be towards the upper end of this range unless significant global action is taken to limit $\mathrm{CO}_{2}$ emissions [1]. Energy is, however, essential to almost every aspect of our lives; the challenge is to maintain economic growth but with reduced energy consumption. The use of renewable energy, rather than fossil fuels, and stringent energy efficient measures are needed to achieve this.

Buildings and its related activities are one of the key contributors to greenhouse gas emissions, for example, in the UK the energy consumed in buildings accounted for $46 \%$ of the nation's total energy consumption in the year 2000 [2] and about half of the nation's carbon emissions are associated with energy use in buildings [3]. High $\mathrm{CO}_{2}$ emissions are often associated with high energy demands and it is also true that the more non-renewable energy is being used, potentially the more $\mathrm{CO}_{2}$ is emitted. The current building stock in China is responsible for 37\% of the nation's total energy consumption and by 2020 this figure is projected to rise to $46.7 \%$, and energy consumption per unit treated floor area in China is more than three times higher than in other developed countries such as the US, UK \& Japan [4]. Therefore, there is significant potential in China to improve the energy efficiency in buildings. China has become one the largest energy consumers nowadays alongside with its high speed economic growth over the past decades. Improving energy efficiency in buildings not only reduces the demands for end use energy but also helps to mitigate the global concerns of climate change by reducing the large amount of $\mathrm{CO}_{2}$ emissions.

Space conditioning consumes a large portion of the energy used in non-domestic buildings particularly for fully air-conditioned (AC) buildings. Alternative approaches to AC buildings such as natural ventilation are now gaining popularity. The PROBE studies reported the monitored energy use and $\mathrm{CO}_{2}$ emissions for 20 public and commercial buildings [5]. The monitored results showed natural ventilation has the potential for reducing building energy consumption and also offering an improved indoor environment compared with conventional mechanical ventilation and airconditioned systems. Natural ventilation is the use of the natural driving forces of wind and temperature difference (buoyancy) to achieve ventilation flow for buildings. The simple form of natural ventilation is often limited to small scale, shallow plan buildings where the internal environment is exposed to exterior directly through operable vents or windows. The internal air speed, temperature and air quality would have rather quick responses to 
changes in external conditions. Therefore, in its simplest form, natural ventilation is unlikely to deliver acceptable conditions in severe climates characterised by hot summers and cold winters.

Modern non-domestic buildings tend to be large and deep plan with sealed façades for security and noise control. In such cases, where simple forms of natural ventilation are unlikely to deliver sufficient ventilation performance, advanced natural ventilation (ANV) strategies should be considered [6]. Architectural features such as atria, lightwells, and tall chimneys (stacks) are often used in an ANV system in order to boost the stack effects for natural ventilation. As described by Lomas [6], ventilation strategies can be classified as Edge-in, Centre-out (E-C), Centre-in, Edge-out (C-E), Edge-in, Edge-out (E-E) and Centre-in, Centre-out (C-C). Existing examples of ANV buildings which have used one or more of the above ventilation strategies include the Queens Building at De Montfort University, Leicester, where E-C strategy was used [7,8]; the Frederick Lanchester Library at Coventry University where C-C and C-E strategies were used [9-11]; and the School of Slavonic and East European Studies at University College London where the C-E strategy was used [12]. These buildings, being UK-based, are subject to a less severe, temperate climate making natural ventilation a more feasible design option.

Although natural ventilation on its own is only applicable to a limited range of climates, a hybrid ventilation system, using a natural ventilation strategy combined with a mechanical system, can extend the applicability of natural ventilation in more severe climatic conditions. Two of the challenges associated with hybrid ventilation design are determining the performance of the passive system and maximising the period of operation of the passive system (which includes attention to the building's fabric and form). Computer simulation is recommended to help address challenges such as these, associated with innovative, sustainable design [13]. Computational fluid dynamics (CFD) and dynamic thermal simulation (DTS) have been used widely to assess the performance of passive systems (e.g. [14,15]). More recently computer simulation was used in the design of a hybrid ventilation system for a library building for Judson College near Chicago in the USA [16,17]. The hybrid ventilation strategy was needed to cope with the severe winter cold and summer warmth experienced in the mid-west USA (Fig. 1a). The library building uses the E-C approach with localised E-E ventilation for perimeter offices. The library also shows how the mechanical systems can be integrated without the additional cost of ducts, controls and false ceilings etc, normally associated with AC buildings [17]. The research of Short \& Lomas [16] has shown that with the hybrid approach the summer time cooling loads were less than half those in a standard US air-conditioned building and the period for which mechanical cooling was needed decreased from seven months to around three months. The climate conditions in Hangzhou are similar to Chicago in the mid-seasons but with a relatively hotter and more humid summer (Fig. 1b). Therefore, a hybrid ventilation system which is suitable for Chicago may well be applicable in a climate such as Hangzhou, a city about 110 miles south-west of Shanghai.

The design of a Science and Technology Museum (STM) building at a newly developed industrial base on the eastern edge of Hangzhou City offered the opportunity to explore a hybrid approach for ventilation. In this paper, Section 2 describes the building design iterations and Section 3 presents the airflow modelling and analysis. The thermal performance of the building is evaluated in Section 4 and conclusions are drawn in Section 5.

\section{The building design}

The Science and Technology Museum is a four-storey office building with a basement which acts as a plenum for incoming a

RELATIVE HUMIDITY $100 \% 80 \%$

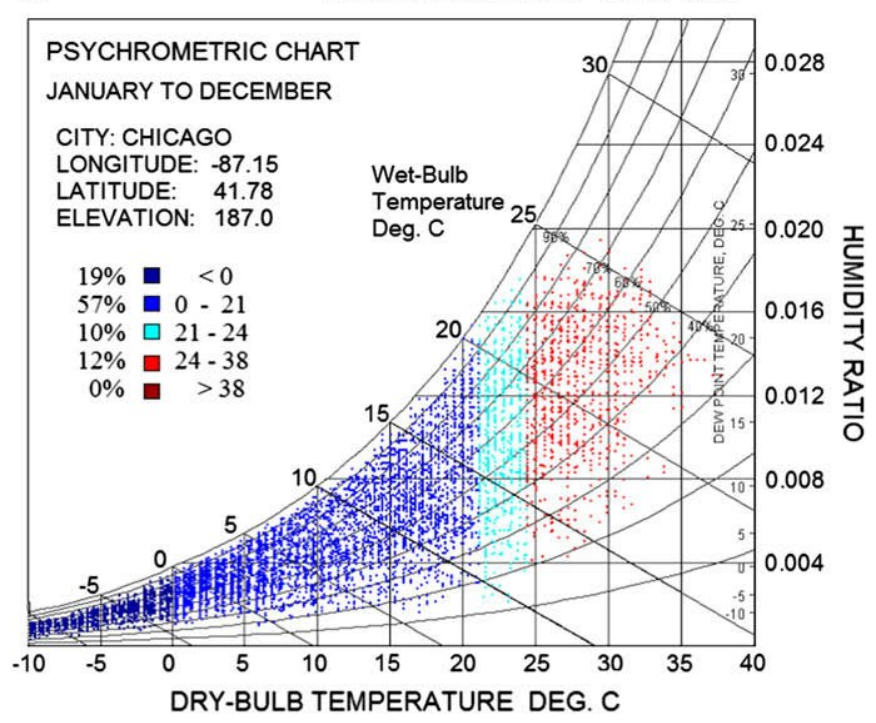

b

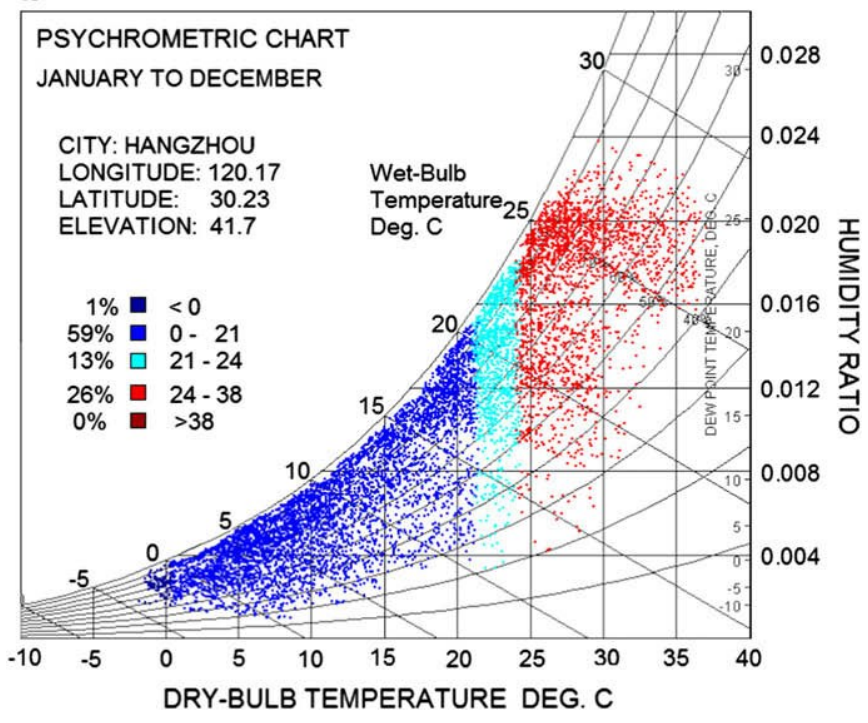

Fig. 1. Psychrometric charts for Chicago (a) and Hangzhou (b).

fresh air when the building is ventilated passively (Fig. 2). The intended operation of the hybrid ventilation system is mechanical cooling/heating mode during hot summer and cold winter periods respectively and during other periods of the year, the building will operate in passive mode (natural ventilation and cooling).

The architectural features of the STM building are similar to the example buildings mentioned in the introduction in that a combination of stacks and a central lightwell are used to draw air through the building using buoyancy forces. Exposed concrete ceilings which have large thermal mass were used in the building in order to increase the night cooling effects during passive operation. The ventilation strategy for this building is 'Edge-in, Centre-out'. Fig. 2a (right) shows that when the building operates in passive mode, cool, fresh air enters the basement and feeds into the 17 vertical shafts naturally; fresh air in the vertical shafts will then enter each ventilation space and stale/polluted air will flow out through the high level vents of each space into a false ceiling surrounding the open central lightwell; the accumulated warm and polluted air will flow above this false ceiling into the central lightwell and then be 

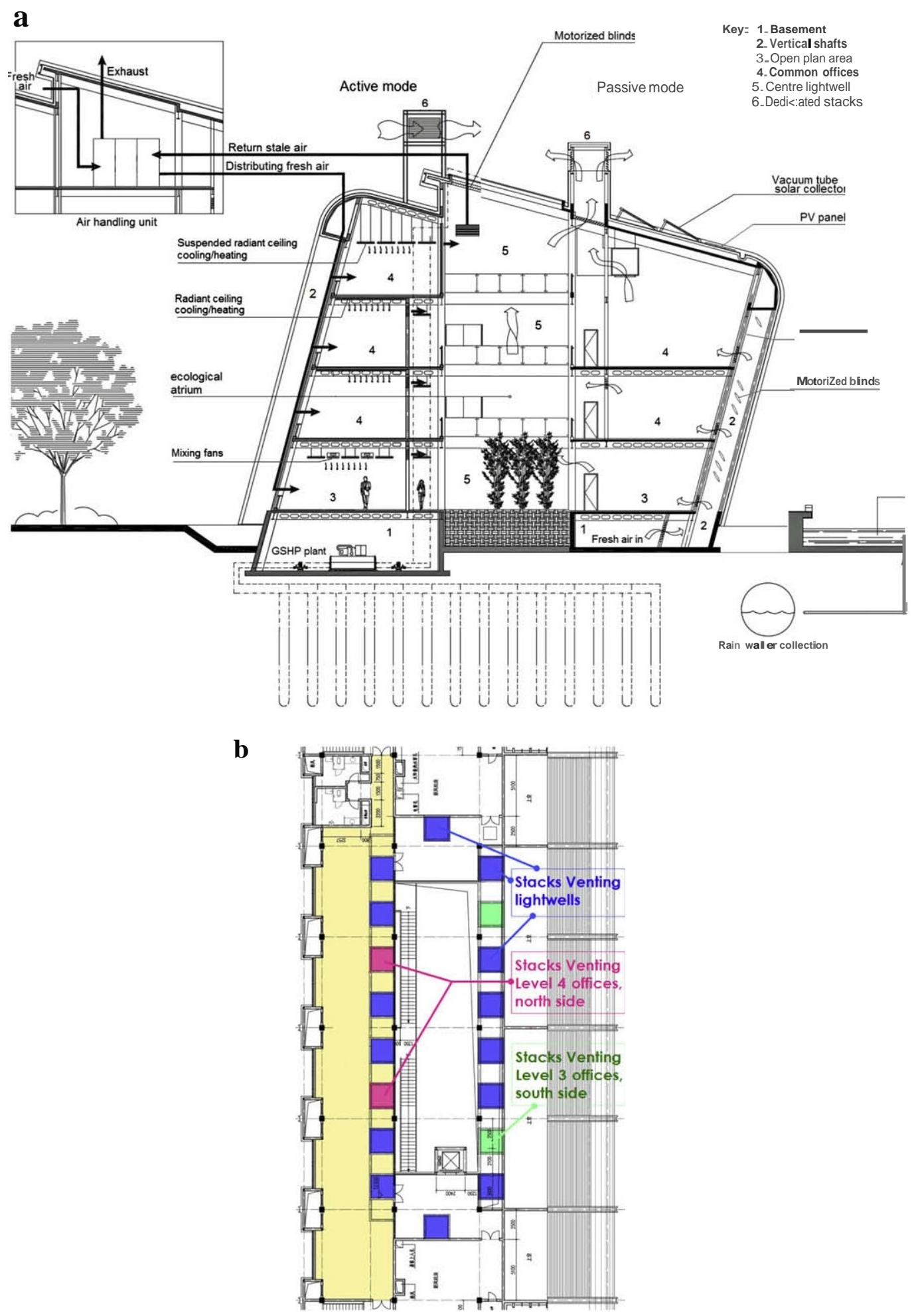

Fig. 2. A section view with arrows showing airflow directions in both active and passive modes (a) and roof plan view showing the stack locations and their functions (b).

driven out through the designated stacks on top of the building. Fig. 2a (left) shows the active mode. For summer cooling, the air handling unit will pre-cool and dehumidify the fresh air, and distribute the conditioned air into each office space separa tely using control valves (the valves will make sure that the fresh air rate to each office space is individually controlled ). The air will be further conditioned by the radiant chilled ceilings. The cooling source for these chilled ceilings is from a Ground Source Heat Pump
(GSHP). The mixing fan will be activated only when the office spaces encounter a sudden change of internal heat gains. For example, a meeting room suddenly becomes fully occupied, the cooling system needs a rapid response with this sudden cha nge. In winter time, the air handling unit will pre-warm the incoming fresh air, the GSHP will switch into winter heating operation, and the summer 'chilled' ceiling surfaces are now swa pped as wa rm radia nt surfaces. When the STM building operates in mechanical mode, the 
basement must be kept as airtight as possible to avoid the loss of conditioned air to the environment. 14 of the 18 stacks surrounding the central lightwell are used to remove air from the lightwell which ventilates air from different levels (Fig. 2b). Two stacks on the south and two stacks on the north side are used to ventilate the offices on levels 3 and 4 respectively. This strategy was established following detailed airflow modelling work (Section 3) which highlighted problems with the original strategy in which exhaust air from all spaces passed into the central lightwell and out through the 18 stacks.

At this concept design stage, initial dynamic thermal simulations for a single space were conducted to evaluate the energy saving potential for the hybrid option compared with a fully mechanical cooling system (Appendix A). The model was constructed in such a way that the key design features such as large thermal mass, passive night venting and mechanical cooling can be realized by a simple control strategy. The result from the simple model showed that the hybrid ventilation option has the potential to save up to $35 \%$ in cooling energy, reassured the design team and provided sufficient evidence to explore this hybrid approach.

\section{Airflow modelling and analysis}

The airflow analysis for the STM building was carried out using the computational fluid dynamics (CFD) program, ANSYS CFX [18]. This state-of-the-art CFD package employs a coupled fully implicit solver based on the finite volume method [19] and uses an unstructured mesh with various element types. Primitive variables (velocity, pressure, enthalpy, etc) are defined at nodes at the corners of each element. Conservation equations are obtained by integration over the elements, creating arbitrary polyhedral control volumes around each node. The solver assembles a single matrix for the entire set of hydrodynamic equations (mass and momentum) and solves them simultaneously. The turbulence model used in this work is the RNG k-epsilon model [20] which has been tested by the authors for modelling buoyancy driven airflows [14,17,21]. Ventilation inlets and outlets at the perimeters of the basement and stacks on the roof are modelled as 'opening' boundaries using the orifice flow equation with a discharge coefficient 0.61 . A zero (relative) pressure is specified on the external side of the opening to represent a no wind scenario. Internal heat gains are modelled as fixed heat flux on surfaces. In all the CFD simulations reported here,

Table 1

Details of CFD model for level 2 - boundary details and CFD predictions.

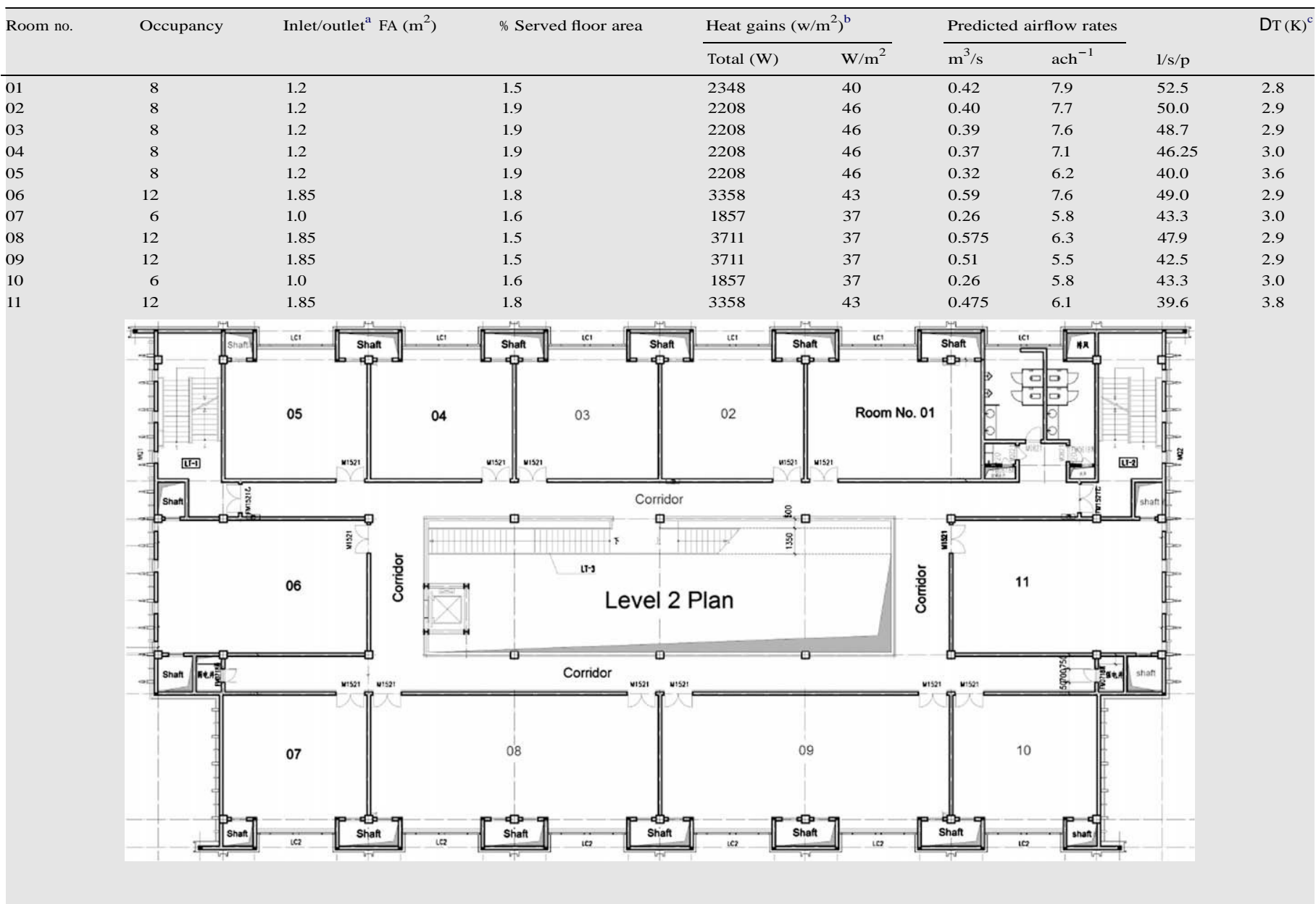

${ }^{a}$ All the inlets are located at the low level of each room feeding from the attached vertical shafts; all outlets are located at high level and exhausting warm to the centre atrium (FA quoted here is the free area of the inlet/outlet).

b Heat gain from an occupant is $90 \mathrm{~W}$, each occupant is allocated a computer with $116 \mathrm{~W}$. These gains are separated by convective (70\%)/radiative (30\%) when modelling. Lighting and solar heat gains are $12 \mathrm{~W} / \mathrm{m}^{2}$ in average in total, the solar gain was obtained through dynamic thermal simulation (Section 4 ) at noon time for a typical summer clear day.

The differencebetween ambient temperature and temperature at $1.4 \mathrm{~m}$ height in modelled spaces. 
a $20{ }^{\circ} \mathrm{C}$ external air temperature was assumed. The effects of solar gain were modelled using dynamic thermal simulation (discussed in Section 4). Based on these results, an internal heat gain of $12 \mathrm{~W} /$ $\mathrm{m}^{2}$ was used to account for the heat gain from lighting and solar penetration.

The CFD analysis involved modelling all the passive ventilated spaces, the supply air shafts and exhaust stacks. The internal heat gains were estimated from the number of people and computers within an individual space. Details of the spaces, their occupancy, heat gains, inlet and outlet sizes, using level 2 as an illustration, are given in Table 1 . The internal gains were distributed to the room surfaces and room air in proportion to their radiant/convective split. The building was modelled assuming that all the spaces were simultaneously fully occupied. The air inlet areas to the basement, from the basement to the vertical shafts, from the vertical shafts to the individual spaces, from the individual spaces to the central lightwell and from the atrium to the exhaust shafts were estimated based on the methods described in [6]. These estimates were adjusted on the basis of preliminary CFD results (not shown). Stack terminals were often designed to prevent wind blowing air back into the stack in an ANV system. The lack of wind during midseasons can be the worst scenario for natural ventilation. For the cases investigated in this paper the effect of wind was therefore ignored. The aims of these analyses were to: (i) identify any hotspots in the building arising from poor ventilation; (ii) study the degree of vertical temperature stratification within the building as a whole and within individual spaces; (iii) suggest refinements to the design to overcome any potential hotspots, and to model these; and (iv) identify any zones where temperatures are unacceptably high (over $27^{\circ} \mathrm{C}$ ).

The preliminary CFD simulations led to a number of modifications to the initial design. High level offices were predicted to be warmer than those on lower levels due to the reduced stack effect. In the original design, level 4 on the north side and level 3 on the south side experienced over-heating due to insufficient ventilation. This led to the design suggestion that these rooms be assigned dedicated stacks (ref. Fig. 2b). The stacks need to be internally partitioned so that air cannot flow out of one room and into another. Additional shafts were added at the east and west ends of the building because the available cross-section area of the original single shafts at each end was insufficient for the occupied spaces they serve. It was proposed to isolate level 4 from the lightwell to prevent stale air from lower levels spilling back onto level 4 and preventing adequate ventilation of the spaces on this level. In the original design with a single shaft at the east and west ends of the building, the openings to level 1 from these two shafts are expected to bring fresh air into level 1 . The simulation results showed that the air actually flows into the two shafts from level 1 . This may be due to the amount of fresh air from the basement into these two shafts is small and the absolute pressure in level 1 at the level of the inlets opening is higher than in the shafts. In a natural ventilation design like the STM building, the buoyancy driving force is larger at low levels than high levels. Opening sizes provided by the shafts from the north and south sides are sufficient enough to ventilate the open plan area on level 1. Therefore, in the proposed design with added shafts at the east and west ends, there are no inlet openings to level 1 .

The predicted ventilation flow rates for individual office spaces, using level 2 as an illustration, are shown in Table 1. Robust ventilation for all the spaces at this level were predicted with volume flows well exceeding the minimum fresh air requirements. As expected, office spaces with large inlet/outlet openings and large internal heat gains have the largest airflows. The temperature increase at $1.4 \mathrm{~m}$ height (the average occupancy height while seating) in level 2 was within the range of $2.8-3.9 \mathrm{~K}$. The temperature difference is to be expected in a displacement ventilation system regime such as this.

The predicted temperature distribution after the design modifications following the preliminary CFD simulations is shown in Fig. 3. Most of the spaces in the building are well ventilated as indicated by temperatures below $27^{\circ} \mathrm{C}$. They show temperature stratification from floor to ceiling ranging from around $20{ }^{\circ} \mathrm{C}$ to $24{ }^{\circ} \mathrm{C}$ (in some room the temperature at ceiling level may be over $26^{\circ} \mathrm{C}$ ). Refinement to the opening areas (i.e. reducing the effective inlet area for level 1 and increasing the effective inlet area for level 3) would result in the flow of air to level 1 being reduced and to level three being increased, therefore diminishing the temperature gradient between floors. This aspect for a typical displacement natural ventilation system was reported in [22] where the suggested ratio of opening sizes at different levels can be used as a reference to adjust the opening size. Further refinement to the ventilation routes for the east and west end offices at level 3 may still be required to mitigate possible over-heating predicted at high level. Dedicated stacks for these spaces may be necessary.

\section{Thermal performance}

The thermal performance of the building was investigated using IES Virtual Environment which is a well established tool for analyzing the dynamic responses of a building based on the hourly input of weather data [23]. The full building model was constructed (Fig. 4a) but only one-sixth of the whole building was modelled (Fig. 4b) in order to reduce modelling complexity. The occupancy and the ventilation sizes at all locations are averaged one-sixth of the whole building and the ventilation scheme of this simplified geometry is kept the same as the whole building. The office spaces in Fig. 4b are named as L1 L (level 1 left), L2 R (level 2 right) etc.

The occupancy time for the model was assumed to be $8 \mathrm{am}-$ $6 \mathrm{pm}$, Monday-Saturday, during this period, heat gains for lighting $\left(12 \mathrm{~W} / \mathrm{m}^{2}\right)$, occupants (90 W each) and computers (116 W each). The total heat gain for office spaces ranged from $35 \mathrm{~W} / \mathrm{m}^{2}$ to $45 \mathrm{~W} / \mathrm{m}^{2}$ from Monday to Friday. On Saturday, the heat gains from occupants and computers were reduced by half (lighting gains remained unchanged). An infiltration rate of $0.2 \mathrm{ach}^{-1}$ was assumed and wind effects were ignored. The heating and cooling set points for the system were $20{ }^{\circ} \mathrm{C}$ and $27{ }^{\circ} \mathrm{C}$ respectively when the mechanical system was in use.

The weather data used in this modelling work were in the CSWD format. It was developed for use in simulating building heating and air-conditioning loads and energy use, and for calculating renewable energy utilization. The model was first run in 'free floating' mode for mid-seasons and summer to examine how the internal

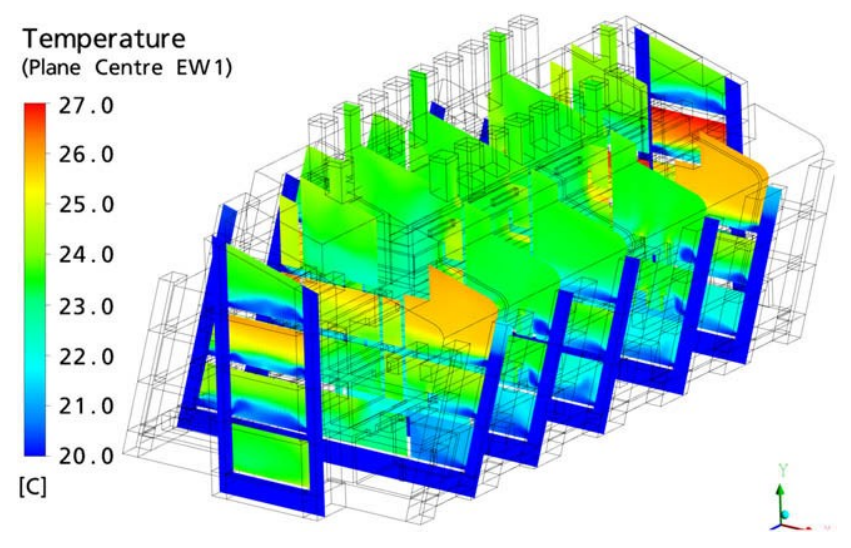

Fig. 3. Predicted temperature distribution throughout the building. 

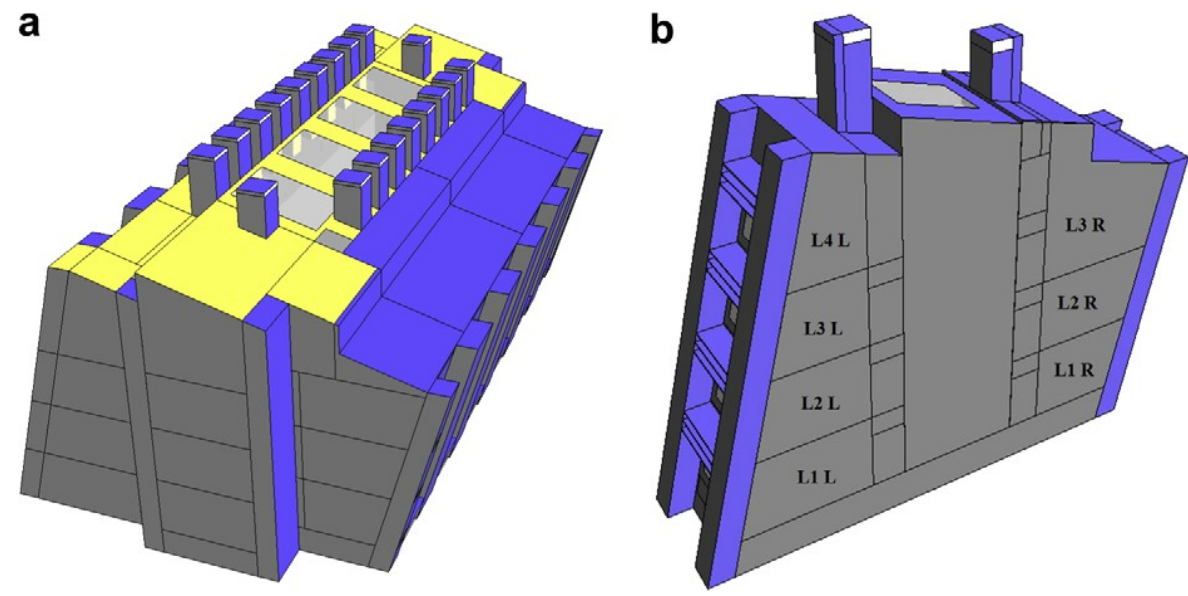

Fig. 4. The full building model (a) and one-sixth of full model (b).

environment responded to the change of exterior conditions when the natural ventilation openings were fully open all the time. The building was then operating in hybrid ventilation mode to evaluate the yearly thermal performance, such as temperatures, $\mathrm{CO}_{2}$ levels, ventilation rates etc. ${ }^{\text {a }}$ Pure mechanical cooling mode was also run to investigate the energy saving potential compared with hybrid ventilation. In pure mechanical cooling mode the building was ventilated at the minimum required ventilation rate, heated to $20{ }^{\circ} \mathrm{C}$ and cooled to $27{ }^{\circ} \mathrm{C}$. Given the minimum ventilation rate needed to maintain satisfactory $\mathrm{CO}_{2}$ levels, winter heating loads were similar for the two modes as shown by the concept design simulation (Appendix A).

In order to model the effect of a Building Management System (BMS) and the likely performance of the building, a simple control strategy was applied for the hybrid ventilation mode. The mode is based on the complementary mixed mode design strategy described in [24,25]. In the building modelled here, the basement external openings, the openings of the inlets along the vertical air supply shafts, the outlets of each individual office space and the outlets along the top of the perimeter of the stacks were determined by either the internal air temperature compared with the external DBT or by the $\mathrm{CO}_{2}$ concentration, during the occupied period or passive night venting when needed. In the heating seasons, the passive venting openings are opened to a level (say about $10-15 \%$ of their full free venting areas) to allow fresh air to enter the building freely during occupied period (maintaining the $\mathrm{CO}_{2}$ level). The passive venting openings are fully shut outside the occupancy time to minimize the heat loss. When cooling was needed during occupancy the passive venting openings are closed; while at night time the passive venting openings are regulated by the difference between the ambient temperature and office temperature - whether night cooling was activated or not depended on how much lower the ambient temperature was than the indoor temperature.

For the hybrid ventilation mode, the following controls were assumed in the DTS model:

- Heating and cooling set points are $20^{\circ} \mathrm{C}$ and $27^{\circ} \mathrm{C}$ respectively during occupied periods.

\footnotetext{
a The Chinese National Standard of Indoor Air Quality (GB 13338 - 2002) [26] and Building Regulation for Offices (JGJ $67-2006)$ [27] require: Temperature $\left(24-27^{\circ} \mathrm{C}\right.$ for summer; $18-22{ }^{\circ} \mathrm{C}$ for winter); $\mathrm{CO}_{2}$ concentration $(<0.1 \%)$; Ventilation rate (20-30 $\mathrm{m}^{3} / \mathrm{h} / \mathrm{p}$ ); Relative humidity ( $<65 \%$ for summer).
}

- Mechanical ventilation at a rate of $30 \mathrm{~m}^{3} / \mathrm{h} / \mathrm{p}$ when: $\mathrm{T}_{\mathrm{i}}-\mathrm{T}_{0}:: 1 \mathrm{~K}$ or $\mathrm{CO}_{2}::: 1000 \mathrm{ppm}$ (where $\mathrm{T}_{\mathrm{i}}$ is the office air temperature and $T_{0}$ is the ambient temperature). This control criterion was applied to all office spaces.

- Basement inlets and stack outlets:

a) during occupied periods, when $\mathrm{T}_{0}<10{ }^{\circ} \mathrm{C}$, dampers open to $25 \%$; when $15{ }^{\circ} \mathrm{C}<\mathrm{T}_{0}<26{ }^{\circ} \mathrm{C}$, dampers open $100 \%$; when $10{ }^{\circ} \mathrm{C}:: \mathrm{T}_{0} \ldots: 15{ }^{\circ} \mathrm{C}$, dampers are regulated linearly from $25 \%$ to $100 \%$;

b) for night venting (from $10 \mathrm{pm}$ to $7 \mathrm{am}$ ), when $\mathrm{T}_{0}<13{ }^{\circ} \mathrm{C}$ the dampers are closed, when $15{ }^{\circ} \mathrm{C}<\mathrm{T}_{0}<26{ }^{\circ} \mathrm{C}$, the dampers are fully opened; for $13{ }^{\circ} \mathrm{C}:: \mathrm{T}_{0} \cdots: 15{ }^{\circ} \mathrm{C}$, the dampers are opened linearly from $0 \%$ to $100 \%$. Night venting was not modelled during Saturday night into Sunday morning because there was no occupancy on Sundays.

- Office space inlet openings along vertical shafts and the outlet openings at high level to central lightwell:

a) from $8 \mathrm{am}$ to $6 \mathrm{pm}$, Monday to Saturday, when $\mathrm{T}_{0}<13{ }^{\circ} \mathrm{C}$, dampers open to $10 \%$; when $\mathrm{T}_{0}>20^{\circ} \mathrm{C}$, dampers open fully; when $13{ }^{\circ} \mathrm{C}:: \mathrm{T}_{0} \cdots 20^{\circ} \mathrm{C}$, dampers are regulated linearly from $25 \%$ to $100 \%$, the criteria $\mathrm{T}_{\mathrm{i}}-\mathrm{T}_{\mathrm{o}}>1 \mathrm{~K}$, and $\mathrm{CO}_{2}<1000$ ppm must also be satisfied;

b) for night venting (from 10pm to $7 \mathrm{am}$ ), when $\mathrm{T}_{0}<15{ }^{\circ} \mathrm{C}$ the dampers are shut, when $\mathrm{T}_{0}>17^{\circ} \mathrm{C}$, the dampers are fully open, and when $15{ }^{\circ} \mathrm{C}: \cdots: \mathrm{T}_{0}: \cdots: 17{ }^{\circ} \mathrm{C}$, the dampers are opened linearly from $0 \%$ to $100 \%$, the criterion $\mathrm{T}_{\mathrm{i}}-\mathrm{T}_{0}>1 \mathrm{~K}$ must also be satisfied.

For pure mechanical cooling, ventilation rate for each office space was fixed to meet the minimum fresh air requirements and the space was cooled to $27{ }^{\circ} \mathrm{C}$.

\section{1. 'Free floating' mode}

Figs. 5-7 show the weekly thermal performance of a typical office space (L2R, for this instance) when running the system in free floating mode. The dry resultant temperature was maintained below $27{ }^{\circ} \mathrm{C}$ most of the time during the mid-season as shown by a typical week in May (Fig. 5). Here the room dry resultant temperature (DRT) was the average of the room air (dry-bulb) temperature and mean radiant temperature. Fig. 5 shows that the external dry-bulb temperature (DBT) was below $20{ }^{\circ} \mathrm{C}$ while the DRT remains above $20{ }^{\circ} \mathrm{C}$ due to the heat gains from the previous days on Monday morning. The increase of DRT during the day time was caused by the internal heat gains and solar gains through the 


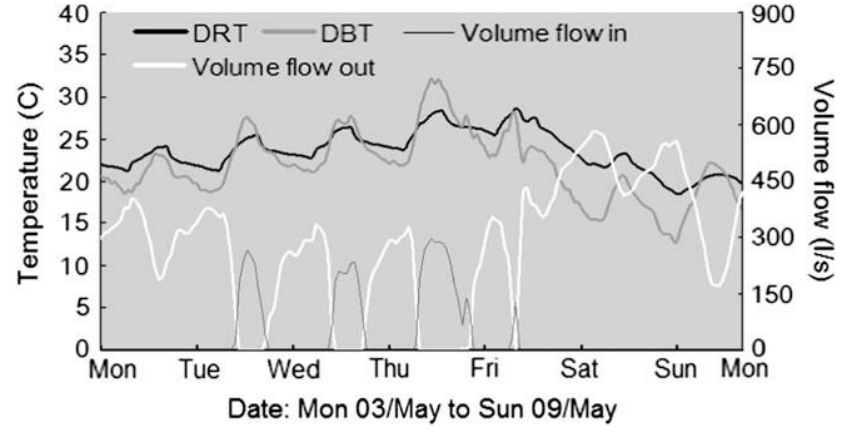

Fig. 5. Simulation results for a typical week in May.

office. When the external DBT drops during the night the DRT follows due to ventilation. This pattern was repeated during the following days. It is worth noting that even when the external DBT exceeded $32{ }^{\circ} \mathrm{C}$ the DRT was able to remain around $28^{\circ} \mathrm{C}$, about $4^{\circ}$ below the external DBT. This indicates that the thermal mass of the building is effective in stabilizing the internal environment. The airflows in Fig. 5 show the volume flow for the office space L2 R at its high level vents between the occupied space and the central lightwell. 'Volume flow out' represents the anticipated flow direction from L2 R to the lightwell while 'volume flow in' represents flow in the opposite direction (reverse flow). It can be seen that the reverse flow occurs when the internal air temperature is lower than the external temperature in which case, air in the occupied spaces drains out through openings at low level because it is more dense. This causes warm air to flow back into the building through high level vents. In reality this could be avoided by reducing the opening size or by switching to mechanical ventilation.

Fig. 6 shows the typical summer thermal response of the building. The external DBT was low on Monday and the DRT in the office space $\mathrm{L} 2 \mathrm{R}$ was below $27^{\circ} \mathrm{C}$ through ventilation. In the following days the external DBT increased and ventilation alone was unable to maintain comfort - the DRT exceeded $27^{\circ} \mathrm{C}$ from Thursday onwards. Reverse flow occurred more often as the external DBT increased, and the internal heat gains, solar gains, ventilation and infiltration all contributed to the increasing of the office space DRT.

Fig. 7 shows the hottest week in summer. The average DRT exceeded $32{ }^{\circ} \mathrm{C}$ and rarely dropped below the external DBT (reserved flow is less likely to happen). The night time ventilation rate was high but the 'cooling' provided through ventilation was not sufficient to produce thermally comfortable conditions in the office space the next day.

Table 2 shows the number of hours for which various temperatures are exceeded. For all the office spaces evaluated, the number of hours over $27{ }^{\circ} \mathrm{C}$ was about $19-22 \%$ for the whole year. For the

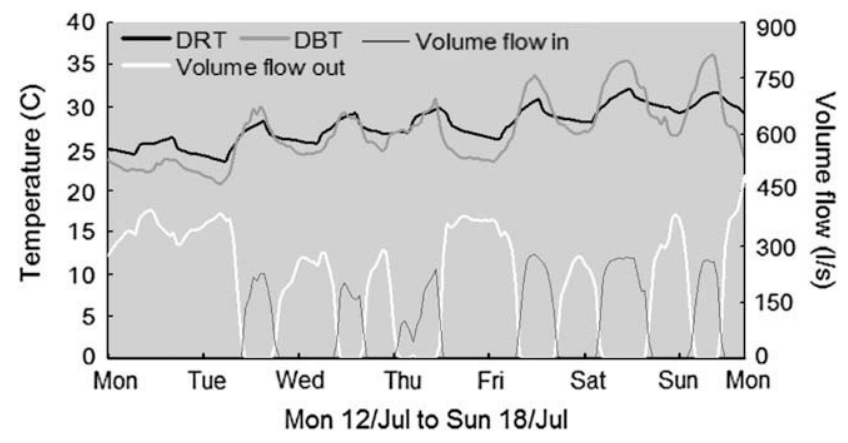

Fig. 6. Simulation results for a typical summer week in July

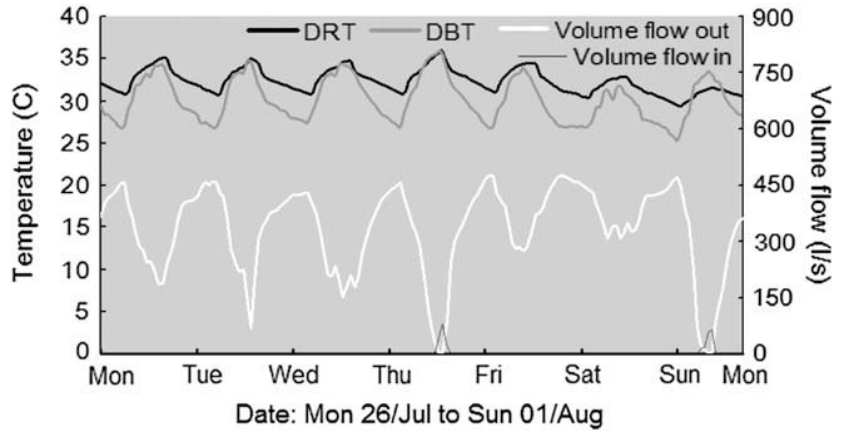

Fig. 7. Simulation results for the hottest week.

occupied time of the year, as shown in Table 3, the percentage ranged from 28 to 32 of occupied hours. This large percentage of occupancy time over the comfort criteria indicates that a mechanical cooling system is needed.

\subsection{Hybrid ventilation and pure mechanical ventilation modes}

The modelling results for a typical winter week for the office space L2 L are shown in Fig. 8. The external DBT is lower than $10{ }^{\circ} \mathrm{C}$ for most of the week. A heating system was used to maintain the internal DRT above its set point $20^{\circ} \mathrm{C}$ during occupancy time (Fig. 8a). The volume flow rates through the space vary due to the changing temperature difference between the external DBT and the internal DRT. On Wednesday there was the least ventilation flow (due to the smallest temperature difference), which caused an increase of $\mathrm{CO}_{2}$ concentration as shown in Fig. 8b. With the large temperature difference between inside and outside, the average ventilation rate was about $3.5-4 \mathrm{ach}^{-1}$ even when the natural ventilation openings were opened only by $10-15 \%$ of their overall free area. In practice, a more sophisticated building management system will control the minimum fresh air to be brought in to meet the ventilation rate and to control $\mathrm{CO}_{2}$ levels in order to save heating energy. In winter time, solar energy was beneficial for heating up the office spaces. In practice, the external shading blinds (Fig. 2) of the building will be adjusted, based on the solar angle, in order to maximize gains from the solar radiation in winter and minimize them in summer for the office spaces. This has not been explicitly investigated because the simulation geometry was setup in such a way that maximum shading effects are obtained during mid-seasons and summer.

Fig. 9 shows the thermal performance of the office space L2 L during mid-seasons when the internal DRT can be maintained within comfort temperature without the use of mechanical cooling. On Thursday, there was a time period when the external DBT was higher than the internal DRT during occupancy. The control system was able to detect the $\mathrm{CO}_{2}$ concentration and the temperature

Table 2

Number of hours when dry resultant temperature exceeds certain values (all hours in the year included).

\begin{tabular}{lllllllll}
\hline Rooms & \multicolumn{2}{l}{ DRT $\left({ }^{\circ} \mathrm{C}\right)$} & & & & & & \\
\cline { 2 - 8 } & $>25.0$ & $>26.0$ & $>27.0$ & $>28.0$ & $>29.0$ & $>30.0$ & $>31.0$ & $>32.0$ \\
\hline L1 L & 2539 & 2142 & 1744 & 1451 & 1134 & 842 & 578 & 337 \\
L1 R & 2520 & 2108 & 1723 & 1441 & 1114 & 820 & 559 & 331 \\
L2 L & 2649 & 2246 & 1857 & 1550 & 1234 & 946 & 661 & 422 \\
L2 R & 2632 & 2222 & 1834 & 1528 & 1206 & 901 & 636 & 388 \\
L3 L & 2583 & 2152 & 1793 & 1505 & 1171 & 863 & 609 & 394 \\
L4 L & 2646 & 2253 & 1856 & 1530 & 1201 & 916 & 670 & 415 \\
L3 R & 2649 & 2308 & 1905 & 1558 & 1243 & 941 & 685 & 419 \\
\hline
\end{tabular}


Table 3

Number of hours when dry resultant temperature exceeds certain values (only the occupied hours in the year included).

\begin{tabular}{lccclllll}
\hline Rooms & \multicolumn{1}{l}{ DRT $\left({ }^{\circ} \mathrm{C}\right)$} & & & & & \\
\cline { 2 - 8 } & $>25.0$ & $>26.0$ & $>27.0$ & $>28.0$ & $>29.0$ & $>30.0$ & $>31.0$ & $>32.0$ \\
\hline L1 L & 1174 & 1006 & 852 & 723 & 583 & 448 & 346 & 235 \\
L1 R & 1175 & 996 & 838 & 726 & 578 & 444 & 344 & 233 \\
L2 L & 1239 & 1074 & 910 & 775 & 656 & 523 & 392 & 290 \\
L2 R & 1222 & 1044 & 893 & 761 & 634 & 487 & 377 & 268 \\
L3 L & 1209 & 1027 & 878 & 762 & 623 & 476 & 375 & 277 \\
L4 L & 1207 & 1040 & 889 & 742 & 596 & 468 & 377 & 273 \\
L3 R & 1206 & 1051 & 891 & 760 & 614 & 470 & 374 & 269 \\
\hline
\end{tabular}

difference between the external DBT and DRT, and activate the mechanical ventilation system, whilst simultaneously, reducing the passive ventilation openings to avoid reverse flow. The mechanical ventilation rate was determined by the standard requirement of $30 \mathrm{~m}^{3} / \mathrm{h} / \mathrm{p}$ [27] (about $102 \mathrm{l} / \mathrm{s}$ for this space). This ventilation rate can maintain the $\mathrm{CO}_{2}$ concentration below the standard request (1000 ppm, see Fig. 9b, on Thursday). For the other four days of this week, the $\mathrm{CO}_{2}$ concentrations were much less than the standard requirements. This indicates that passive natural ventilation can improve indoor air quality by bringing sufficient fresh air into the office spaces. Fig. 9 also shows passive ventilation during occupancy time, alongside night ventilation. The temperature difference between internal DRT and external DBT allows the space to be ventilated naturally at night due to thermal buoyancy. The resulting large natural ventilation rates $\left(250-300 \mathrm{l} / \mathrm{s}\right.$ or 5-6 $\mathrm{ach}^{-1}$ ) are able to overcome the potential heat gains (shown in Fig. 9b) and maintain the internal DRT within the comfort level without the use of cooling. On Thursday there was no airflow through passive ventilation opening when the fan venting was activated but without cooling (Fig. 9a on Thursday) to avoid back flow. This illustrates how the system respond with the control strategies used for hybrid ventilation.
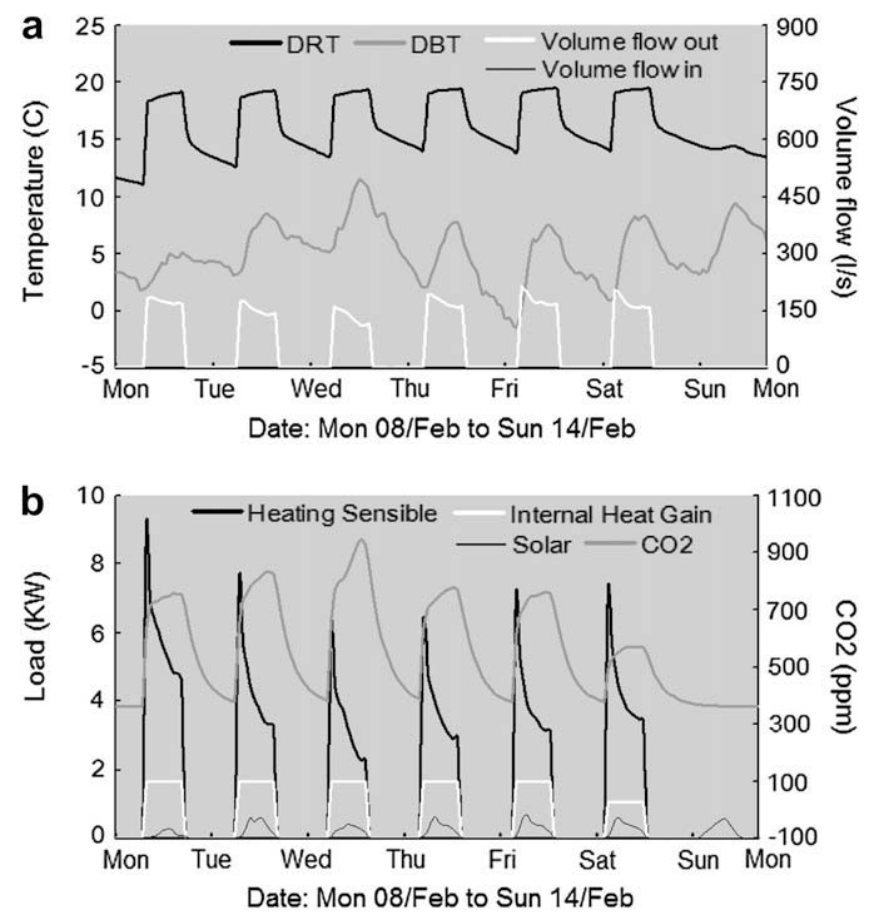

Fig. 8. The modelling results for a typical winter week in office space L2 L (a) DRT, DBT and ventilation rate at office space high level outlet and (b) Heating sensible loads, internal heat gains, solar gains and $\mathrm{CO}_{2}$ concentration.
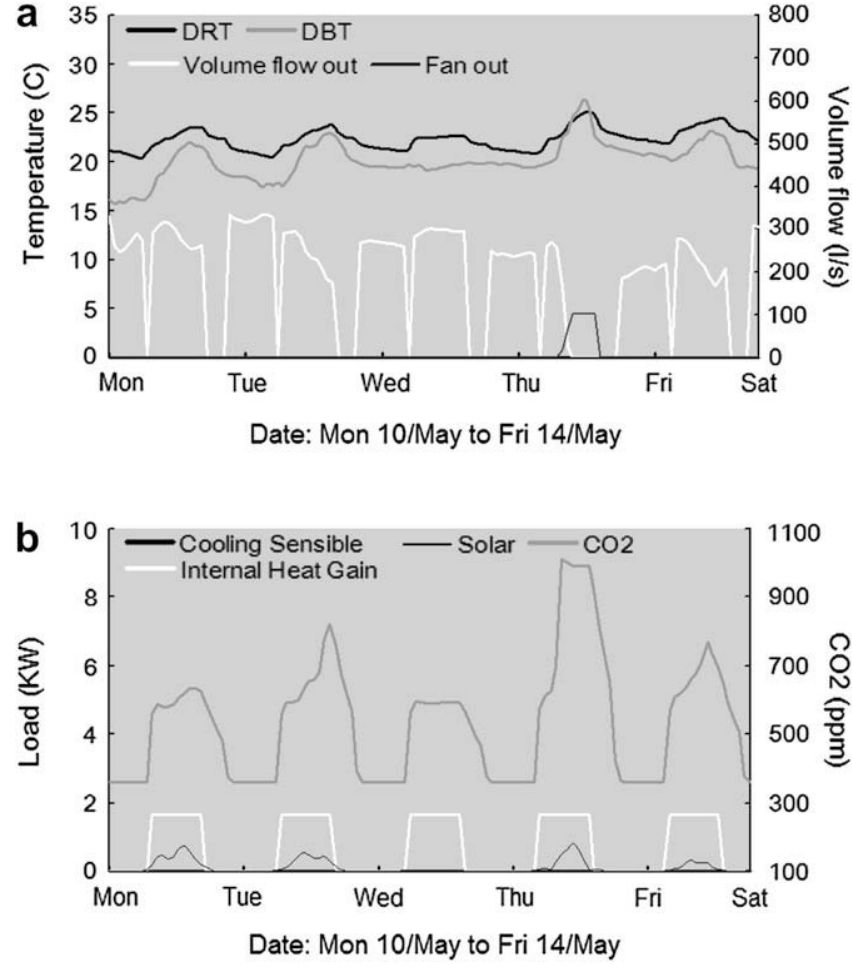

Fig. 9. The modelling results for a typical mid-season week in office space L2 L (a) DRT, DBT, ventilation rate at office space high level outlet and fan extract rate; and (b) Cooling sensible loads (0), internal heat gains, solar gains and $\mathrm{CO}_{2}$ concentration.

The thermal response of the building for four working days in June is shown in Fig. 10. The internal DRT was controlled within the comfort zone by mechanical cooling during most of the occupancy period (Fig. 10a). The external DBT can drop to $20{ }^{\circ} \mathrm{C}$ during night times, therefore night venting was beneficial for cooling the
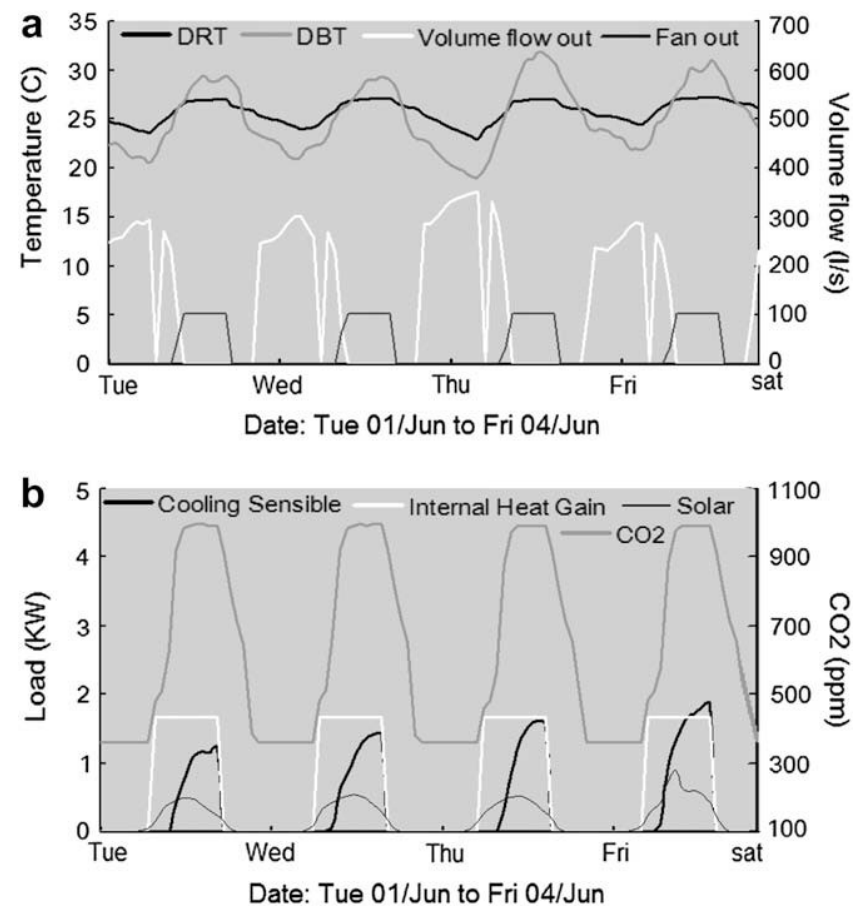

Fig. 10. The modelling results for a typical summer week in office space L2 L (a) DRT, DBT, ventilation rate at office space high level outlet and fan extract rate; and (b) Cooling sensible loads, internal heat gains, solar gains and $\mathrm{CO}_{2}$ concentration. 
building fabric, which will reduce the day time mechanical cooling loads. At the beginning of the working period, the internal DRT was below $27{ }^{\circ} \mathrm{C}$ so for a short time period the building was still ventilated passively. When passive ventilation was not able to maintain the comfort temperature the mechanical cooling system was activated to achieve this (about midday on Tuesday). The $\mathrm{CO}_{2}$ concentration (Fig. 10b) remained close to the standard requirement with the ventilation rate provided by the mechanical cooling system (about $30 \mathrm{~m}^{3} / \mathrm{h} / \mathrm{p}$ ).

During the hottest week of the year the mechanical cooling system operated during all occupied hours to maintain comfort within office spaces using the minimum required ventilation rate (Fig. 11a). The resulting $\mathrm{CO}_{2}$ concentration was maintained at about 1000 ppm (Fig. 11b) and the passive night ventilation occurred less often, and the night cooling effects for DRT were not obvious from Fig. 11a. This indicates that the building would have to rely on the mechanical system completely at times like this, and the passive system should be fully shut.

Fig. 12 shows the $\mathrm{CO}_{2}$ concentrations and relative humidity for office $\mathrm{L} 1 \mathrm{R}$ for the whole year. The requirement to maintain indoor $\mathrm{CO}_{2}$ concentrations below $1000 \mathrm{ppm}$ was met at all times [26,27]. The highest $\mathrm{CO}_{2}$ concentration was due to the mechanical ventilation with minimum required ventilation rate at $30 \mathrm{~m}^{3} / \mathrm{h} / \mathrm{p}$ (Fig. 12a). Fig. 12b clearly shows that the relative humidity rises above the standard requirement limit ( $\mathrm{RH}<65 \%$ ) during the hot and humid summer. The incorporation of dehumidification within the cooling system, to remove the moisture in air, would be needed to maintain the relative humidity level below the standards' requirement.

Table 4 shows the annually sensible cooling loads, cooling and fan energy consumptions for all the spaces when the building was running in hybrid ventilation mode, while Table 5 shows the same but with the building running in pure mechanical cooling mode (in Jan, Feb, Nov and Dec, cooling is not needed in either mode). As proposed for this STM building at the design stage, a ground source
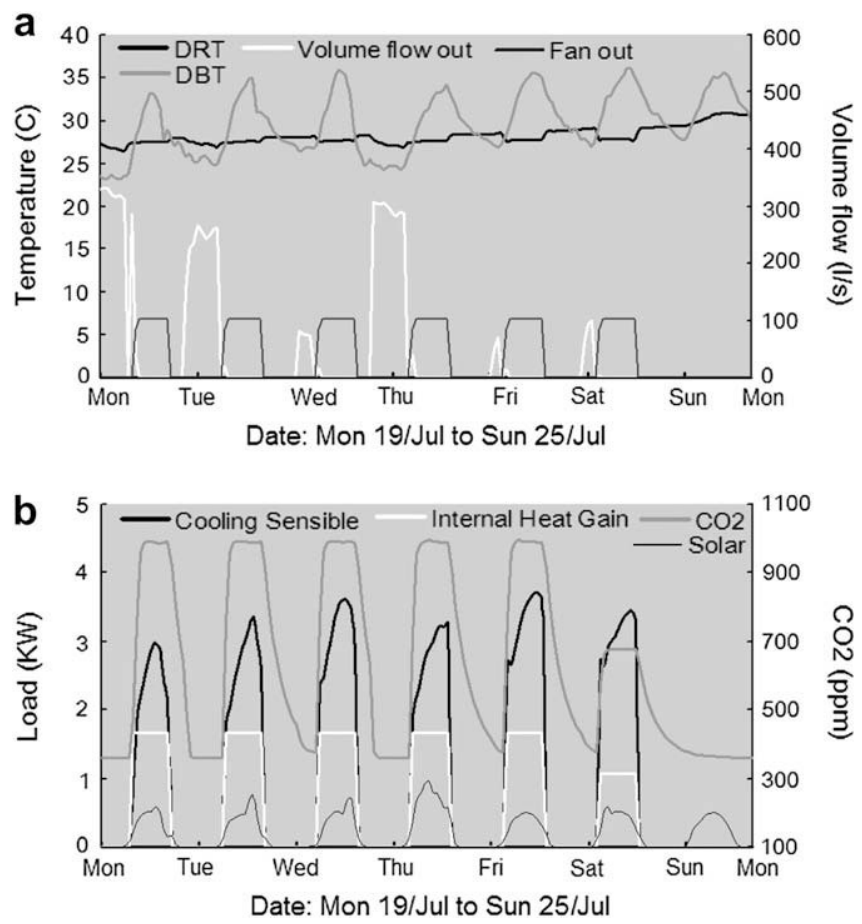

Fig. 11. The modelling results for the hottest week in office space L2 L (a) DRT, DBT, ventilation rate at office space high level outlet and fan extract rate; and (b) Cooling sensible loads, internal heat gains, solar gains and $\mathrm{CO}_{2}$ concentration.
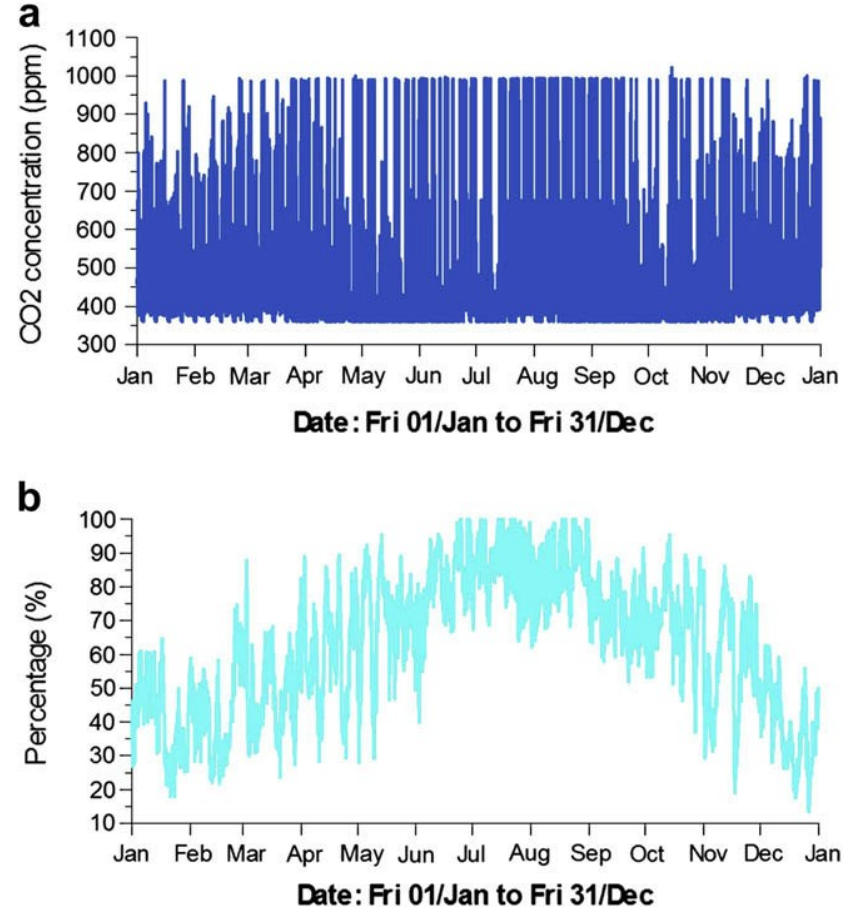

Fig. 12. Model predictions of yearly (a) $\mathrm{CO}_{2}$ concentration (b) and relative humidity for room L1 R.

heat pump system will be used to assist space heating and cooling. There was no COP (coefficient of performance) information for cooling and heating at the time when the modelling work was carried out. The cooling efficiency was assumed to be 3.0 and the specific fan power was $0.53 \mathrm{~W} /\left(\mathrm{m}^{3} / \mathrm{h}\right)$ referencing the Chinese public building standard [28]. These values were used to calculate the annual energy consumptions in Tables 4 and 5.

The potential saving of the annual cooling energy consumptions for hybrid ventilation compared with pure mechanical ventilation

Table 4

Sensible cooling loads for modelled spaces in hybrid ventilation mode.

\begin{tabular}{|c|c|c|c|c|c|c|c|}
\hline & \multicolumn{7}{|c|}{ Sensible cooling load (MWh) } \\
\hline & L1 L & L1 R & L2 L & L2 R & L3 L & L4 L & L3 R \\
\hline Mar 01-31 & 0 & 0 & 0 & 0 & 0 & 0 & 0 \\
\hline Apr $01-30$ & 0 & 0 & 0.0009 & 0 & 0.0001 & 0 & 0 \\
\hline May 01-31 & 0.019 & 0.0206 & 0.0321 & 0.0241 & 0.0221 & 0.0085 & 0.0105 \\
\hline Jun $01-30$ & 0.2826 & 0.2582 & 0.2931 & 0.2756 & 0.233 & 0.2165 & 0.2943 \\
\hline Jul 01-31 & 0.6152 & 0.5491 & 0.589 & 0.5823 & 0.4773 & 0.495 & 0.7036 \\
\hline Aug 01-31 & 0.778 & 0.6878 & 0.7456 & 0.7481 & 0.6049 & 0.6525 & 0.9463 \\
\hline Sep 01-30 & 0.1326 & 0.1278 & 0.1752 & 0.1663 & 0.1487 & 0.116 & 0.1705 \\
\hline Oct $01-31$ & 0 & 0.0006 & 0.003 & 0.0019 & 0.0015 & 0 & 0 \\
\hline Sum total & 1.8275 & 1.6441 & 1.8388 & 1.7982 & 1.4876 & 1.4885 & 2.125 \\
\hline $\begin{array}{l}\text { MV rate }(1 / s) \text { for } \\
\text { each office }^{a}\end{array}$ & 96.3 & 102.2 & 59.6 & 61.1 & 44.2 & 34.5 & 57.0 \\
\hline Fan energy (KWh) & 205.5 & 221.2 & 105.8 & 111.5 & 80.9 & 66.3 & 110.2 \\
\hline $\begin{array}{l}\text { Cooling energy } \\
\text { (KWh) }\end{array}$ & 609.2 & 548.0 & 612.9 & 599.4 & 495.9 & 496.2 & 708.3 \\
\hline Floor Area $\left(\mathrm{m}^{2}\right)$ & 59.3 & 39.5 & 50.7 & 48.1 & 42.2 & 48.8 & 56.6 \\
\hline $\begin{array}{l}\text { Annual Cooling } \\
\left(\mathrm{KWh} / \mathrm{m}^{2}\right)\end{array}$ & 10.3 & 13.9 & 12.1 & 12.5 & 11.8 & 10.2 & 12.5 \\
\hline $\begin{array}{l}\text { Annual Fan Energy } \\
\left(\mathrm{KWh} / \mathrm{m}^{2}\right)\end{array}$ & 3.5 & 5.6 & 2.1 & 2.3 & 1.9 & 1.4 & 1.9 \\
\hline
\end{tabular}

${ }^{\mathrm{a}}$ Mechanical ventilation whenever fan is activated either due to cooling or lack of ventilation (i.e. when thermal buoyancy force is insufficient to drive an adequate ventilate flow for office spaces). 
Table 5

Sensible cooling loads for modelled spaces in pure mechanical cooling mode.

\begin{tabular}{|c|c|c|c|c|c|c|c|}
\hline & \multicolumn{7}{|c|}{ Sensible cooling load (MWh) } \\
\hline & L1 L & L1 R & L2 L & L2 R & L3 L & L4 L & L3 R \\
\hline Mar 01-31 & 0 & 0 & 0.0005 & 0 & 0 & 0 & 0 \\
\hline Apr $01-30$ & 0.0043 & 0.0061 & 0.0177 & 0.0115 & 0.0122 & 0.0022 & 0.0016 \\
\hline May 01-31 & 0.0997 & 0.0927 & 0.2466 & 0.2056 & 0.1926 & 0.1123 & 0.1433 \\
\hline Jun 01-30 & 0.435 & 0.386 & 0.5147 & 0.4871 & 0.408 & 0.377 & 0.523 \\
\hline Jul 01-31 & 0.808 & 0.7076 & 0.7815 & 0.7746 & 0.6262 & 0.6749 & 0.9558 \\
\hline Aug 01-31 & 0.8845 & 0.7779 & 0.8369 & 0.8384 & 0.6732 & 0.7428 & 1.0621 \\
\hline Sep 01-30 & 0.3967 & 0.3523 & 0.4933 & 0.48 & 0.3902 & 0.3674 & 0.5265 \\
\hline Oct $01-31$ & 0.0269 & 0.0269 & 0.083 & 0.068 & 0.0608 & 0.0331 & 0.048 \\
\hline Sum total & 2.6552 & 2.3493 & 2.9743 & 2.8653 & 2.3631 & 2.3098 & 3.2603 \\
\hline $\begin{array}{l}\text { MV rate } \\
\text { (l/s) for each } \\
\text { office }^{a}\end{array}$ & 96.3 & 102.2 & 59.6 & 61.1 & 44.2 & 34.5 & 57.0 \\
\hline $\begin{array}{l}\text { Fan energy } \\
\text { (KWh) }\end{array}$ & 575.1 & 610.3 & 355.9 & 364.9 & 264.0 & 206.0 & 340.4 \\
\hline $\begin{array}{l}\text { Cooling energy } \\
\text { (KWh) }\end{array}$ & 885.1 & 783.1 & 991.4 & 955.1 & 787.7 & 769.9 & 1086.8 \\
\hline Floor Area $\left(\mathrm{m}^{2}\right)$ & 59.3 & 39.5 & 50.7 & 48.1 & 42.2 & 48.8 & 56.6 \\
\hline $\begin{array}{l}\text { Annual Cooling } \\
\left(\mathrm{KWh} / \mathrm{m}^{2}\right)\end{array}$ & 14.9 & 19.8 & 19.6 & 19.9 & 18.7 & 15.8 & 19.2 \\
\hline $\begin{array}{l}\text { Annual Fan Energy } \\
\left(\mathrm{KWh} / \mathrm{m}^{2}\right)\end{array}$ & 9.7 & 15.5 & 7.0 & 7.6 & 6.3 & 4.2 & 6.0 \\
\hline
\end{tabular}

${ }^{\text {a }}$ Mechanical ventilation throughout of the year, venting from $8 \mathrm{am}$ to $6 \mathrm{pm}$, Monday to Saturday, with $3130 \mathrm{~h}$ in total.

is about $30-35 \%$, which is similar with the results produced for the concept design modelling (Appendix A). Annual energy consumptions by fan venting for the two space conditioning strategies show significant differences, the hybrid ventilation consumed about onethird of that used by pure mechanical ventilation. In hybrid ventilation mode, fan ventilation (with the same ventilation capacity as the mechanical ventilation mode) is only activated when mechanical cooling is needed and when the natural driving force of thermal buoyancy is insufficient to ventilate office spaces (for example, when the internal and external temperature difference is small). For pure mechanical ventilation mode, fan ventilation follows the space conditioning routine: $8 \mathrm{am}-6 \mathrm{pm}$, MondaySaturday, venting the designated office spaces with minimum flow rate of fresh air to keep the $\mathrm{CO}_{2}$ below what the standard requests $[26,27]$.

\section{Conclusions}

Computer simulations were used to optimize and evaluate a hybrid ventilation building design in south China. The simulation results have shown that the hybrid ventilation is a feasible low energy approach for non-domestic building design even for subtropical climates such as south China.

A full scale CFD model was used to illustrate how well the office spaces can be ventilated in the passive mode for an external temperature of $20{ }^{\circ} \mathrm{C}$. Most of the occupied spaces were adequately ventilated by buoyancy driven natural ventilation flow assisted by the central lightwell and the tall stacks of the building. The modelling showed that spaces on high levels (i.e. level 3 at south side and level 4 at north side) should have their own designated stacks, and partitions within the stack may be needed to prevent any potential flow from one room to the other. There is also a need to introduce a new vertical shaft at the east and west end of the building to supply air to the end rooms at levels 2 and 3. Refinement to opening areas would further improve the temperature distribution between floors and prevent any potential over-heating.

Dynamic thermal simulations were also carried out to investigate the likely thermal performance of the new building design.
With the proposed hybrid ventilation strategy the building was able to maintain the thermal comfort criteria suggested by the relevant national standards and building regulations. One-sixth of the full building was simulated to represent the full building's hybrid ventilation principles but to reduce the complexity of the model. The simulation results showed that the 'free floating' mode is unlikely to meet the comfort criteria due to the severe climate condition in summer. The hybrid ventilation approach, however, is able to cope with the summer warms and effectively utilize the benefit of passive natural ventilation. With appropriate control strategies, passive night ventilation could be used to cool the building fabric and reduce the potential cooling loads during the following day. The comparison of annual sensible cooling loads and electric consumptions between pure mechanical cooling and hybrid ventilation shows that the cooling energy saving potential of the proposed hybrid ventilation design was about $30-35 \%$. The hybrid ventilation system could not only save cooling energy, but also improve indoor air quality during mid-seasons when the building was able to run passively to maintain thermal comfort.

It should be noted that the current control strategies did not include a dehumidification device to control the humidity of indoor environments. In reality the hybrid ventilation scheme would need such a device. This would not undermine the energy saving potential of the hybrid ventilation strategy compared with standard air-conditioning, which would also include the similar dehumidification device.

Appendix A. : Construction and simulation details for a simple office space

Fig. A1 is a simple office space used for concept design development. The width, depth and height of the space are $8.0 \mathrm{~m}, 7.5 \mathrm{~m}$ and $3.5 \mathrm{~m}$ respectively. A window $(5.0 \mathrm{~m}$ by $3.3 \mathrm{~m})$ is located in the centre of the south facing wall. Assuming that the space is taken out from a large building, except the side with a window, other sides including roof and floor are surrounded by other office spaces therefore an adiabatic condition is used for these sides. A solid plate overhang is fixed above the window to represent the shading effects (width: $8.0 \mathrm{~m}$, depth: $3.3 \mathrm{~m}$, not shown).

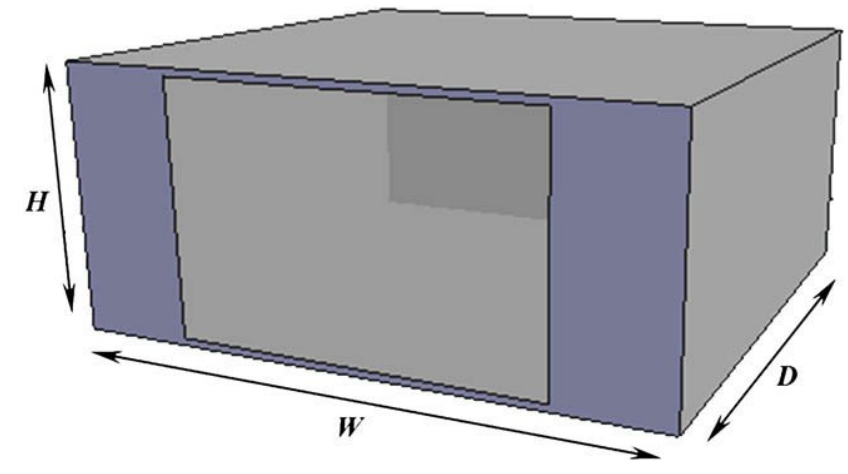

Fig. A1. A sample office space.

The construction details are: roof: $0.2 \mathrm{~m}$ Cast Concrete (Dense); sidewalls: $0.2 \mathrm{~m}$ Concrete block (light weight); back wall: $0.2 \mathrm{~m}$ Cast Concrete; floor: $15 \mathrm{~mm}$ Synthetic Carpet on top of $20 \mathrm{~mm}$ Plywood (light weight); front wall: $150 \mathrm{~mm}$ Cast Concrete \& EPS SLAB (100 mm insulation) \& $150 \mathrm{~mm}$ light weight metallic cladding; glazing: Low-e double glazing. The internal heat gains are $40 \mathrm{~W}$ per treated floor area from Monday to Friday, and $30 \mathrm{~W} / \mathrm{m}^{2}$ on Saturday. The evaluation package is IES VE [23]. 


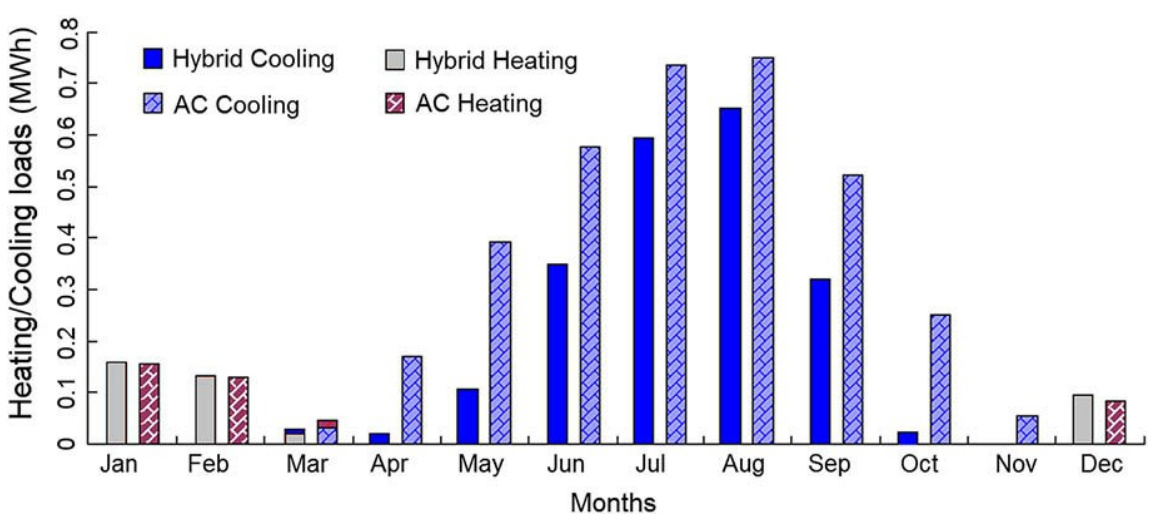

Fig. A2. Annual heating \& cooling loads of the space for AC \& hybrid ventilation systems

For standard air-conditioning (AC) mode, the operating hours are from $8 \mathrm{am}$ to $6 \mathrm{pm}$, Monday to Saturday, heating to $20^{\circ} \mathrm{C}$ and cooling to $27{ }^{\circ} \mathrm{C}$ with a fixed ventilation rate $50 \mathrm{l} / \mathrm{s}$.

For hybrid mode, the operating criteria are set out as follows:

(a) : Day time ventilation (where, $\mathrm{T}_{0} 1 / 4$ outside temperature, $\mathrm{T}_{\mathrm{i}} 1 / 4$ indoor temperature)

1. Winter heating: If $\mathrm{T}_{0}<1 / 46^{\circ} \mathrm{C}$, winter heating to set point $20{ }^{\circ} \mathrm{C}$ with venting rate $50 \mathrm{l} / \mathrm{s}$

2. Mid-seasons:

2.1 If $\mathrm{T}_{\mathrm{o}}>6{ }^{\circ} \mathrm{C} \& \mathrm{~T}_{\mathrm{i}}<22{ }^{\circ} \mathrm{C}$, heating to set point $20{ }^{\circ} \mathrm{C}$ with ventilation rate $50 \mathrm{l} / \mathrm{s}$

2.2 If $22{ }^{\circ} \mathrm{C}<1 / 4 \mathrm{~T}_{\mathrm{i}}<27{ }^{\circ} \mathrm{C}$

2.2.1 \& if $\mathrm{T}_{0}<\mathrm{T}_{\mathrm{i}}-2 \& \mathrm{~T}_{0}>6{ }^{\circ} \mathrm{C}$ with ventilation rate $175 \mathrm{l} / \mathrm{s}$

2.2.2 \& if $T_{0}>1 / 4 T_{i}-2$ with ventilation rate $50 \mathrm{l} / \mathrm{s}$

3. Summer cooling: if $\mathrm{T}_{\mathrm{i}}>1 / 427^{\circ} \mathrm{C}$, cooling to set point $26{ }^{\circ} \mathrm{C}$ with ventilation rate $50 \mathrm{l} / \mathrm{s}$

(b) : Night venting (10pm-6am), if $16<\mathrm{T}_{\mathrm{o}}<\mathrm{T}_{\mathrm{i}} \& \mathrm{~T}_{\mathrm{i}}>20{ }^{\circ} \mathrm{C}$, night cooling at $175 \mathrm{l} / \mathrm{s}$

The predicted sensible heating and cooling loads were converted to energy use using coefficients of 0.91 and 3.0 for heating and cooling respectively (Fig. A2). The heating loads for the two running modes are similar but the cooling demands are considerably reduced for hybrid ventilation. A total saving in cooling load of up to $35 \%$ was predicted.

\section{References}

[1] IPCC. WGI fourth assessment report - summary for policymakers. Paris; Feb 2007. Available from: http://www.aaas.org/news/press_room/climate_change/ media/4th_spm2feb07.pdf [accessed 06.01.09].

[2] CIBSE Guide F. Energy efficiency in buildings. 2nd ed. London: The Chartered Institution of Building Services Engineers, ISBN 190328734 0; 2004.

[3] The BRE guide 2006. Part L explained, (C) copyright BRE; 2006. ISBN 1860819109.

[4] IGEEB. Memoirs on intelligent building and green building 3. In: Proceedings of third international conference on intelligent green and energy efficient building. Beijing, China; Mar 2007. ISBN 978-7-112-09143-0. p. 274-59.

[5] Bordass B, Cohen R, Standeven M, Leaman A. Assessing building performance in use: energy performance of the PROBE buildings. Building Research and Information 2001;29(2):114-28.

[6] Lomas KJ. Architectural design of an advanced naturally ventilated building form. Energy and Buildings 2006;39(2):166-88, ISSN 03787788.
[7] Simons MW, Moloney BJ. Comfort and acoustic monitoring in a large naturally ventilated technically advanced building. International Journal of Ventilation 2003;2(1):1-14.

[8] BRECSU. The Queens building, De Montfort University, new practice final report 102. Department of the Environment; 1997.

[9] Pidwell S. Deep heat: Lanchester library by short \& assoc. Architecture Today 2001;115:38-49, ISSN 0958-6407.

[10] Cook MJ, Lomas KJ, Eppel H. Design and operating concept for an innovative naturally ventilated library. In: Proceedings of conference CIBSE '99, Harrogate, UK; 1999. p. 500-07, ISBN 0900953977.

[11] Krausse B, Cook MJ, Lomas KJ. Environmental performance of a naturally ventilated city centre library. Energy and Buildings 2007;39(7):792-801, ISSN 03787788.

[12] Short CA, Lomas KJ, Wood A. Design strategy for low-energy ventilation and cooling within an urban heat island. Building Research and Information 2004;32(3):187-206, ISSN 0961-3218

[13] Kennett S. Model answer. September 2001. Building Services Journal 2001a:42-3.

[14] Cook MJ, Short CA. Natural ventilation and low energy cooling of large, nondomestic buildings - four case studies. The International Journal of Ventilation 2005;34:283-94, ISSN 1473-3315.

[15] Kennett S. Air space. September 2001. Building Services Journal 2001b:45. [16]

Short CA, Lomas KJ. Exploiting a hybrid environmental design strategy in a US continental climate. Building Research and Information 2007;35(2):119-43, ISSN 0961-3218.

[17] Lomas KJ, Cook MJ, Fiala D. Low energy architecture for a severe US climate: design and evaluation of a hybrid ventilation strategy. Energy and Buildings 2006;39(1):32-44, ISSN 03787788.

[18] Ansys Cfx. Available from: http://www.ansys.com/products/cfx.asp [accessed 31.01.08]; 2007.

[19] Versteeg HK, Malalasekera W. An introduction to computational fluid dynamics - the finite volume method. 2nd ed. Harlow, England: Pearson Education Ltd; 2007.

[20] Yakhot V, Orszag SA, Thangham S, Gatski TB, Speziale CG. Development of turbulence models for shear flows by a double expansion technique. Phys Fluids A 1992;4(7):1510-20.

[21] Cook MJ, Lomas KJ. Buoyancy-driven displacement ventilation flows: evaluation of two eddy viscosity models for prediction. BSERT 1998;19(1): 15-21.

[22] Ji Y, Cook MJ. Numerical studies of displacement natural ventilation in multistorey buildings connected to an atrium. BSERT 2007;28(3):207-22, ISSN 0143-6244

[23] IES. Integrated environmental solutions ltd. Available from: http://www.iesve. com [accessed 31.01.08]; 2007.

[24] Chartered Institute of Building Services Engineers. Applications manual 13 mixed mode ventilation. London: CIBSE; 2000.

[25] Chartered Institute of Building Services Engineers. Guide B2 - ventilation and air conditioning. London: CIBSE; 2001.

[26] GB/T 18883. China national standard: indoor air quality standard (issued on 01 November, 2002, implemented on 01 March, 2003); 2002.

[27] JGJ 67. China building regulations: office building (implemented on 01 May, 2007); 2006.

[28] GB 50189. Design standard for energy efficiency of public buildings (issued on 04 April, 2005, implemented on July 2005); 2005. 